\title{
'FESTINA LENTE': THE ILO AND EU AGENDAS ON THE DIGITAL TRANSFORMATION OF WORK
}

Nastazja POTOCKA-SIONEK ${ }^{*}$, Antonio ALOISI ${ }^{\dagger}$

\section{This is a pre-edited work that has been accepted for publication in the International Journal of Comparative Labour Law and Industrial Relations,} Volume 37, Issue 1 (2021)

\begin{abstract}
This article compares the International Labour Organization (ILO) and European Union (EU) agendas concerning the digital transformation of work, and addresses possible policy gaps and their implications for international and EU labour law. It critically reviews the current social acquis of both institutions and concentrates on the key analogies between the ILO's Centenary Declaration for the Future of Work and some of the various regulatory initiatives taken by EU institutions in the context of the Pillar of Social Rights. The article finds that, despite the often articulated calls for urgent and original measures, both institutions' programs present largely a prudent continuation of traditional narratives, failing to strengthen the adequacy of existing labour regulation regimes. Besides their predominantly non-binding nature, the efficacy of the most futureoriented instruments is profoundly undermined by the unreasonable exclusion of those workers who bear most of the brunt of social disparities accelerated by digitalization and casualization of work. Also, the implementation of these initiatives may be jeopardized by complex governance methods and never soothed tensions between conflicting approaches and objectives. The study concludes that, although positive signs are emerging in the supranational legal order, much remains to be done to address the multifarious challenges brought about by the digital transformation.
\end{abstract}

\section{Keywords}

International Labour Organization, European Union, European Social Law, digital transformation, platform work, social policy, future of work, labour regulation

\footnotetext{
* Ph.D. researcher, European University Institute, Florence. Email: nastazja.potocka-sionek@eui.eu † Assistant professor, IE Law School, IE University, Madrid. Email: antonio.aloisi@ie.edu Antonio Aloisi's contribution to this study was carried out within the framework of the 'Boss Ex Machina' project, which has received funding from the European Union's Horizon 2020 Research and Innovation Programme under the Marie Skłodowska-Curie grant agreement No 893888. We are grateful to Valerio De Stefano for generating a great discussion and to the anonymous reviews for providing invaluable feedback.
} 


\section{INTRODUCTION: NAVIGATING UNCHARTED LEGAL WATERS}

The last decade will likely be remembered for the spectacular rise of digitally mediated work and the unprecedented development of robotics, algorithms, and artificial intelligence. In some cases, these transformational new realities represent a positive evolutionary leap, but more often they worsen pre-existing social vulnerabilities. These phenomena have complicated the longstanding problem of how socio-legal institutions should respond to changing patterns of work. In particular, the dynamics and volume of technological change have reignited discussions on the allegedly narrow scope of application of labour regulation, the adequacy of definitions of workers' legal status, and the sustainability of labour and social security paradigms.

Technology is forcefully reshaping the labour markets, accelerating global inequalities and intensifying power imbalances between management and labour. The transnational, deterritorialized and fragmented character of work organized through digital infrastructure strains the regulatory capacities of domestic legislators. Potent (tech) companies exploit legal loopholes, leading to regulatory arbitrage, social dumping, and a race to the bottom. Consequently, the need to envisage adequate supranational responses is critical on the agendas of the International Labour Organization (ILO) and the European Union (EU). Over the last couple of years, these institutions have acknowledged the vast potential brought about by technological progress, but also the urgency to 'correct' negative externalities that lead to profound vulnerabilities, social exclusion, and political resentment.

Both the ILO and the EU strongly advocate towards building an adaptable labour market and securing the rights of non-standard workers, who are often excluded from the scope of labour and social protection. The paramount objective of providing decent work for all and ensuring a 'human-centred approach' in the digital age has been at the core of the ILO's Future of Work Initiative - a major project launched to mark the centenary of the Organisation (2019). A key document is the Centenary Declaration for the Future of Work, adopted at the $108^{\text {th }}$ International Labour Conference to chart a path for the next hundred years. At the European level, the goal of strengthening the social dimension of the EU has been notably reflected in the European Pillar of Social Rights (EPSR), as well as in the key initiatives of its roll-out, the main one being the new Directive 2019/1552 on transparent and predictable working conditions.

The present article critically examines these most recent supranational regulatory and policy initiatives and situate them in the acquis of both orders. We do not explore in detail the principal underlying phenomenon - new forms of work related to new technologies, such as work in the platform economy - a topic that has been extensively covered by scholars in the 
last few years. ${ }^{1}$ We argue, somewhat counterintuitively, that it makes little sense for regulators to focus merely on digitally driven forms of work. Rather, the immense challenge is to reinvent the socio-legal model by adopting more encompassing and elastic solutions instead of implementing exemptions that end up turning some work formats into low-cost alternatives. Indeed, labour scholars have long been warning against technological exceptionalism and piecemeal regulations. The agendas of the ILO and the EU are based on the premise that the downsides of the digital transformation should be countered by securing effective protection for the most unprotected workers. Yet, as we seek to demonstrate, the policy measures undertaken to renew the social contract for the digital age and to ensure the smooth functioning of labour markets can be summarized with the Latin oxymoron 'festina lente' ('make haste slowly'). Both institutions' 'future of work' agendas ${ }^{2}$, despite having generated great expectations of sustainable, future-oriented solutions, could be more aptly described as 'today's work' agendas, presenting largely a prudent continuation of traditional narratives. This mismatch between vows and outcomes risks undermining the credibility of the institutional programs.

Hence, the overarching goal of our analysis is to address possible policy gaps and further implications for international and EU labour law, by exploring the lessons to be drawn from recent regulatory tendencies and taking into account the well-established yet delicate dialogue between the two legal orders. ${ }^{3}$ Such a reflection is timely, especially now that the centenary celebrations have come to an end, and first steps have been taken to translate the provisions of the Declaration into action. What is more, the year 2019 was marked by implementation of several important developments following up on the EPSR. Understanding the key trajectories and anticipating the potential shortcomings of the policy narratives is especially vital also in the context of the COVID-19 crisis. This pandemic puts socio-legal foundations under extreme strain, urging us to test the suitability of the regulatory instruments yet again. ${ }^{4}$ We hope that our

\footnotetext{
${ }^{1}$ Eurofound, Employment and working conditions of selected types of platform work, Luxembourg (2018); Valerio De Stefano, The rise of the just-in-time workforce: On-demand work, crowdwork, and labor protection in the gigeconomy, 37 Comp. Lab. L. \& Pol'y J., 461-71. For more recent accounts, see also Jerzy Wratny \& Agata LuderaRuszel, eds., New Forms of Employment: Current Problems and Future Challenges (Springer Fachmedien Wiesbaden 2020); Jamie Woodcock \& Mark Graham, The Gig Economy: A Critical Introduction (Polity 2020). For a comparative account of various domestic polices see Isabelle Daugareilh, Christophe Degryse, \& Philippe Pochet, The Platform Economy and Social Law: Key Issues in Comparative Perspective, ETUI Research PaperWorking Paper (2019).

${ }^{2}$ We use this term in the article to describe both the ILO's Future of Work Initiative, as well as the various EU policy and regulatory measures tackling the digitalisation and the 'future of work' broadly speaking.

${ }^{4}$ Nicola Countouris, Valerio De Stefano, Keith Ewing, \& Mark Freedland, Covid-19 Crisis Makes Clear a New Concept of 'Worker' Is Overdue (2020), https://bit.ly/3cGEbQk.
} 
contribution will inform the debate on policy intervention and multilateral collaboration needed at the supranational level.

The article proceeds as follows. After this introduction, Section 2 sets the stage for an analysis of the recent agendas of the ILO and the EU. It situates the present call for urgent and decisive responses to the digital transformation within the context of well-established policies undertaken to adjust to a constantly evolving socio-legal landscape. Section 3 examines a set of core initiatives recently launched by these two institutions: the ILO's Centenary Declaration on the Future of Work; the EU's EPSR and, more specifically, Directive 2019/1552. These are, of course, broad instruments addressing a wide range of issues that fall outside the scope of our analysis. We intend to distil from them the points related to the digital transformation without losing sight of the broader context. Section 4 critically inquires whether enough effort was made to respond to the profound transformations of work. The evaluation focuses on four core points: (1) the originality of the measures; (2) the legal force of the new instruments and the specificity of governance methods; (3) the relevance of a collective governance and social dialogue to regulate new forms of work in the digital age; and (4) the credibility of a shift towards a universal model of worker protection. Section 5 concludes that, despite positive signs emerging in the supranational legal order, there is a lot more to be done to address the multifarious and complex challenges posed by the digital transformation of work. It also reflects on the prospects of tightening the multilateral cooperation between both institutions.

\section{DIAGNOSES OF SOCIAL INSTITUTIONS AND CALLS FOR A REFORM}

[T]he ILO's Centenary coincides with the most profound and transformative process of change in the world of work that it has seen throughout its history. (...) And so, we are not called then to review or revise, or even to add, to the objectives which the ILO was established to pursue, this great social contract for peace and social justice. But we certainly do need to subject to rigorous examination exactly how we intend to realize these objectives.

-ILO Director-General Guy Ryder, addressing the delegates to the $108^{\text {th }}$ International Labour Conference in June $2019^{5}$

The European social model has been a success story and has made Europe a worldclass place to live and work. (...) With the European Pillar of Social Rights the EU

\footnotetext{
${ }^{5}$ See https://bit.ly/2ZiiPom
} 
stands up for the rights of its citizens in a fast-changing world. (...) In times of deep change - whether in life or in politics - it is only natural to come back to what defines you and to what holds you together.

-Jean-Claude Juncker, then President of the European Commission, proclaiming the EPSR in November $2017^{6}$

These quotations encapsulate the core question that the ILO and the EU have been faced with in recent years, namely the adequacy of existing labour law regimes in view of the ongoing transformation. Both organizations have been vocal about the critical need to respond to the key 'megatrends' reshaping the modern world of work. Technological advance, often referred to under tantalizing labels such as the 'Fourth Industrial Revolution', is considered one of the principal drivers of change, together with globalization, climate change, and demographic shift. ${ }^{7}$ It is undeniable that digitalization dramatically changes working patterns and spurs new forms of employment that arguably escape the regulatory paradigm of standard employment. At the very least, the catalyst effect of digitalization can be considered a 'genuine novelty' ${ }^{8}$ The same can hardly be said, however, about the increasing ambiguity of employment classification of many digitally mediated work arrangements and the growing hurdles regarding the applicability of labour standards. These are 'old', one may even say 'typical', issues related to 'atypical' employment that are undergoing a resurgence. ${ }^{9}$

Over the past decades, both the ILO and the EU have proved capable of providing legislative mechanisms to adapt to flexibilization, tertiarization, and casualization of work. ${ }^{10}$ Various ILO instruments have responded to the proliferation of non-standard employment relationships, including the Part-Time Work Convention, 1994 (No. 175), the Home Work Convention, 1996 (No. 177), and the Private Employment Agencies Convention, 1997 (No.

\footnotetext{
${ }^{6}$ See https://ec.europa.eu/cyprus/news/20171117_en

${ }^{7}$ The other phenomena referred to by the ILO as 'megatrends' are globalization, demographic shift, and climate change. For an overview of these trends, see Inception Report for the Global Commission on the Future of Work (International Labour Office - Geneva 2017). Similarly, the OECD has recognized demographic change, globalization, and the digital revolution as three major forces driving the change of the world of work; see Stefano Scarpetta, What Future for Work? 305 OECD Observer Q1 (2016).

${ }^{8}$ Matthew Finkin, Beclouded Work, Beclouded Workers in Historical Perspective, 37 Comparative Labor Law and Policy Journal 617 (2016). For a general discussion of what is 'new' and what is 'old' in the gig economy, see e.g., Jeremias Prassl, Humans as a Service: The Promise and Perils of Work in the Gig Economy (Oxford 2018).

${ }^{9}$ Judy Fudge, The Legal Boundaries of the Employer, Precarious Workers, and Labour Protection, in Boundaries and Frontiers of Labour Law: Goals and Means in the Regulation of Work, 297-315 (Davidov \& Langille eds. Hart 2006).

${ }^{10}$ Eurofound, Labour Market Change: Trends and Policy Approaches Towards Flexibilisation, Challenges and Prospects in the EU series (Publications Office of the European Union 2020).
} 
181). ${ }^{11}$ To regulate the 'first wave' of de-standardization of employment relationships, the EU adopted three directives on so-called atypical employment: Directive 97/81 of 15 December 1997 concerning the Framework Agreement on part-time work, Directive 1999/70 of 28 June 1999 concerning the Framework Agreement on fixed-term work, and Directive 2008/104 of 19 November 2008 on temporary agency work. The central, dual rationale behind these instruments is 'to improve quality of these forms of employment' ${ }^{12}$ and avoid discrimination by approximating the legal situation of non-standard workers to that of standard employees working in the same undertaking. However, in an increasingly heterogeneous environment and due to a plethora of domestic exceptions, the model of 'comparative fairness' may fail to offer solid guarantees for groups of workers once considered peripheral or even residual, and now representing a growing and essential constituent of the global workforce. ${ }^{13}$ One of the key limitations of this approach lies in the narrow and static personal scope of these instruments, which is inextricably linked to the existence of the employment relationship. ${ }^{14}$ Moreover, this strategy has perpetuated dualism between different employment forms, leaving too many aspects inferiorly regulated. ${ }^{15}$

Recent years have amply revealed fundamental weaknesses in the moderate attempt to promote diversity in employment while seeking to regulate the forms of work resulting from this exception-to-rule approach. ${ }^{16}$ As non-standard work has been 'normalized', not to say promoted, to increase employment rates and market competitiveness, ${ }^{17}$ continued endeavours have been made towards a more comprehensive application of rights and standards. Both supranational institutions have been trying to expand the 'gateway' to the protective ambit of

\footnotetext{
${ }^{11}$ ILO, Non-Standard Employment around the World: Understanding Challenges, Shaping Prospects, 323-35 (International Labour Office 2016).

${ }^{12}$ Mark Bell, Between Flexicurity and Fundamental Social Rights: The EU Directives on Atypical Work, 1 European Law Review 31-48 (2012).

${ }^{13}$ In a case concerning an 'on-demand contract', the Court of Justice of the European Union (CJEU) ruled that there was no 'comparator' in the enterprise because all the full-time workers had fixed hours and were obliged to perform the work without being allowed to refuse it. Case C-313/02, Nicole Wippel v Peek \& Cloppenburg GmbH \& Co. $K G$ [2004] ECLI:EU:C:2004:607. For an analysis of the limitations of this approach, see Anne Davies, Regulating Atypical Work: Beyond Equality, in Resocialising Europe in a Time of Crisis, ch. 11 (Countouris \& Freedland eds. CUP 2013).

${ }^{14}$ Nicola Countouris, EU Law and the Regulation of 'Atypical' Work, in Research Handbook on EU Labour Law, 253 (Bogg, Costello, \& Davies eds. Edward Elgar 2016).

${ }^{15}$ Simon Deakin, New forms of employment: Implications for EU-law-The law as it stands (European Labour Law Network $-7^{\text {th }}$ Annual Legal Seminar, The Hague, 2014).

${ }^{16}$ Miriam A. Cherry \& Antonio Aloisi, Dependent Contractors in the Gig Economy: A Comparative Approach, 66 American University Law Review 635-89 (2017).

17 Jill Rubery et al., Challenges and Contradictions in the "Normalising" of Precarious Work, Work, 32 Employment and Society 509-27 (2018).
} 
labour law by stretching the notion(s) of employment - a method achieving attention and consensus. The Employment Relationship Recommendation, 2006 (No. 198) makes it clear that the determination of whether an employment relationship exists should be guided primarily by the concrete facts relating to the performance of work and the remuneration of the worker, regardless of how the contract describes it and in an attempt to mitigate the risk of misclassification. ${ }^{18}$ Similar considerations apply to determining the scope of EU labour law, given the apparently expansive, yet field-specific, interpretation of the concept of 'worker' by the Court of Justice of the European Union (CJEU). ${ }^{19}$ A detailed analysis of these questions is beyond the scope of this article; suffice it to say that despite enduring efforts to apply a broad understanding of the employment relationship, the paradigm of labour protection of exclusively those in an employment relationship may prove narrow and consequently ineffective.

Concomitantly, increasing emphasis has been put on decoupling protection from the sole status of employment. The Declaration on Fundamental Principles and Rights at Work (1998) elevated a set of labour standards to the rank of fundamental rights and principles applying to all workers, regardless of their legal or contractual classification. ${ }^{20}$ Another softlaw initiative, the Decent Work Agenda (1999), established four principles that have guided the ILO policies ever since: the promotion of rights at work; employment; social protection; and social dialogue. ${ }^{21}$ Crucially, the concept of decent work set out by this agenda has not been limited to employment, but covers all the ways that people contribute to society and the economy, including informal work, unpaid work, and self-employment. The Decent Work Agenda has been institutionalized in the Declaration on Social Justice for a Fair Globalisation (2008). Yet this bold recognition of the universal nature of the core labour standards, and the

\footnotetext{
${ }^{18}$ Para. 9, Employment Relationship Recommendation, 2006 (No. 198). The relevance and application of this recommendation in the changing world of work has been well covered in the Report of the Committee of Experts, ILC109/III(B) - Promoting Employment and Decent Work in a Changing Landscape, in particular pp. 81-146.

${ }^{19}$ The notion of worker settled by the Court of Justice of the European Union, developed primarily within the framework of the free movement of workers, is that 'for a certain period of time a person performs services for and under the direction of another person in return for which he receives remuneration'. Case C-393/10, Dermod Patrick O'Brien v Ministry of Justice [2012] ECLI:EU:C:2012:110; Case C-147/17, Sindicatul Familia Constanţa e a. contro Direcţia Generală de Asistenţă Socială şi Protecţia Copilului Constanţa [2018] ECLI:EU:C:2018:926. 'Direction', in the CJEU's jurisprudence, may also refer to tenuous elements of control and subordination. Case C-232/09, Dita Danosa v LKB Lìzings SIA [2010] ECLI:EU:C:2010:674.

${ }^{20}$ These 'core', universally applicable principles are (1) freedom of association and the effective recognition of the right to collective bargaining; (2) the elimination of all forms of forced or compulsory labour; (3) the effective abolition of child labour; and (4) the elimination of discrimination in respect of employment and occupation. These norms are binding upon all Member States of the ILO, even if they have not ratified the conventions guaranteeing these rights.

${ }^{21}$ ILO Director-General, Report Decent Work (1999), https://bit.ly/3gfMHab; ILO, Declaration on Social Justice for a Fair Globalization (2008).
} 
goal of making all work decent rather than all work standard, ${ }^{22}$ are still far from being fully implemented. At the EU level, much in the same vein, this goal leaves a great deal to be desired. Despite the feeble effort toward europeanizing the definition of 'worker,' effet utile is endangered by restrictions at the country level excluding certain forms of work from the application of EU labour law, so uniformity is far from real. ${ }^{23}$ Moreover, although it does not prevent self-employed persons from being granted basic labour and social rights, the traditional 'binary divide' between employment and self-employment still persists. This resonates also in the sphere of antitrust regulations, which prevents the full enjoyment of collective labour rights to workers situated in a (genuine or bogus) grey area. ${ }^{24}$

\section{LEGAL DEVELOPMENTS OF SUPRANATIONAL AGENDAS AND CHALLENGES} AHEAD

Each initiative towards framing a revised regulatory framework must involve carefully assessing existing schemes and perhaps adapting them. This is certainly a vital, if not an inescapable, preliminary step to develop comprehensive and effective policy responses. ${ }^{25}$

\subsection{THE ILO LEVEL: 100 YEARS OF GLOBAL GOVERNANCE OF LABOUR LAW, AND COUNTING}

The Initiative on the Future of Work has been a centrepiece of the ILO's agenda developed to commemorate its 100th anniversary, celebrated in 2019. Proposed in 2013 as one of the seven Centenary Initiatives, ${ }^{26}$ it was elaborated by Director-General Guy Ryder in his Report to the $104^{\text {th }}$ Session of the International Labour Conference (ILC) in $2015^{27}$ and adopted by that Conference. Its primary aim was to provide space to discuss multiple challenges triggered by the ongoing transformation of the world of work, and to reflect on how the ILO and its Member States can best respond to them. Implementation has followed in three stages. During the first stage, the Member States were invited to take part in national tripartite 'centenary conversations' on four topics: work and society, decent jobs for all, the organization of work

\footnotetext{
${ }^{22}$ See International Labour Office, Conclusions of the Meeting of Experts on Non-Standard Forms of Employment (2015), https://www.ilo.org/gb/GBSessions/previous-sessions/GB323/pol/WCMS 354090/lang--en/index.htm.

${ }^{23}$ Case C-216/15, Betriebsrat der Ruhrlandklinik v Ruhrlandklinik [2016] ECLI:EU:C:2016:518.

${ }^{24}$ Adalberto Perulli, Economically dependent/quasi-subordinate (parasubordinate) employment: legal, social and economic aspects. Brussels, European Commission (2003).

${ }^{25}$ Nicola Countouris, Defining and Regulating Work Relations for the Future of Work, 36 (ILO 2019).

${ }^{26}$ Report of the Director-General Report 1(A) Towards the ILO Centenary: Realities, Renewal and Tripartite Commitment, International Labour Conference, 102 ${ }^{\text {nd }}$ Session, 2013, https://bit.ly/31CAqIO

${ }^{27}$ ILO, Report of the Director-General, Report I The Future of Work Centenary Initiative, International Labour Conference, 104th Session, Geneva, 2015, https://bit.ly/3iuMKky
} 
and production, and the governance of work. ${ }^{28}$ The call included international organizations, research institutions, universities, civil society, and individuals. A significant amount of research has been conducted on the 'megatrends' shaping the world of work, ${ }^{29}$ especially the implications of digital innovation, ranging from the much debated prospect of job displacements by robots and AI to the impact on job quality. ${ }^{30} \mathrm{~A}$ series of evidence-rich ILO research papers, issue briefs, and notes informed the prolific work of the Global Commission. ${ }^{31}$

The second stage of the initiative began in August 2017 with the launch of the independent Global Commission on the Future of Work. The objective of this high-level commission was to examine the outputs from the 'centenary conversations' and prepare a report to be presented as a key document to the ILC in June 2019. The launch of its report 'Work for a Brighter Future' on 22 January 2019 officially opened the year celebrating the ILO centenary. ${ }^{32}$ The Future of Work Initiative culminated in the $108^{\text {th }}$ session of the ILC, which adopted the Declaration for the Future of Work (hereafter the Declaration) on 21 June 2019. This instrument has been acclaimed as crucial to setting out the direction of action of the ILO for the next century.

The Declaration firmly states that the ILO shall direct its efforts to harness the fullest potential of technological progress in order to achieve decent work and sustainable development, which ensure dignity, self-fulfilment, and a just sharing of benefits for all (para. II A (ii)). Fundamentally, it emphasizes that the ILO's and Member States' policy responses to digitalization should be anchored in a human-centred approach to the future of work, aiming to 'put workers' rights and the needs, aspirations and rights of all people at the heart of economic, social and environmental policies'. ${ }^{33}$ This call for increasing human agency can be

\footnotetext{
${ }^{28}$ Over 110 Member States have responded to this call and have actively engaged in national dialogues on the future of work. The outcome of these dialogues has been summarized in the Synthesis Report of the National Dialogues on the Future of Work (ILO 2017), https://bit.ly/2ZnmU9g

${ }^{29}$ For a comprehensive review of research on these topics see Thereza Balliester \& Adam Elsheikhi, The Future of Work: A Literature Review, Research Department Working Paper No. 29 (ILO 2018).

${ }^{30}$ An ILO literature review conducted in 2018 estimates that as much as $38 \%$ of the ILO literature on the broadly understood 'future of work' (255 studies) was dedicated to technology. See Balliester \& Elsheikhi, supra n. 29 at 40.

31 The ILO's publications on the future of work are available at https://www.ilo.org/global/topics/future-ofwork/publications/lang--en/index.htm

${ }^{32}$ Work for a Brighter Future - Global Commission on the Future of Work (International Labour Office - Geneva (2019).

${ }^{33}$ Para. I D of the Declaration. Further references to a 'human-centred approach' are made in paras II A, III, and IV F of the Declaration, indicating the centrality of this concept. This definition draws on the Global Commission's report, which framed it as an 'approach that puts people and the work they do at the centre of economic and social policy and business practice'. See Work for a Brighter Future, supra n. 32 at 24.
} 
seen as countermovement, in Polanyi's terms, to the techno-deterministic account of the ongoing transformation or, more broadly, as an 'attempt to re-embed a dominant global market economy in the social realities of those affected, especially workers, with reference to the idea of 'social justice'. 34

The first area of implementation of this agenda focuses on measures geared towards 'strengthening people's capabilities'. The Declaration expresses the ILO's commitment to promote the acquisition of skills by all workers throughout their working life, and identifies this as a joint responsibility of governments and social partners (para. II A iii). The Member States are called upon to invest in the capacities of all people through four core policies: (1) effective realization of gender equality, (2) effective lifelong learning and quality education for all; (3) universal access to comprehensive and sustainable social protection; and (4) effective measures to support people through the transitions they will face throughout their working lives (para. III). The Declaration emphasizes that ensuring human development requires innovative responses to the challenges brought about by technological change. Specifically, it stresses the need to ensure that education systems are responsive to labour market tendencies, to address current and predicted skills gaps, and to achieve better work-life balance. However, the ILO constituents have not embraced the Commission's progressive proposal of a formal recognition of the universal entitlement to lifelong learning. ${ }^{35}$

Second, the human-centred agenda should be achieved through 'strengthening the institutions of work' to ensure adequate protection of all workers, without distinction whatsoever. The Declaration reasserts that the institutions of work are not redundant but still valid and should be revitalized. While it recognizes the primary role of the private sector in job creation, innovation, and decent work, it also highlights the continued importance of public regulation of markets. This key assertion rests on the premise that such public intervention is prerequisite for the functioning of market economies and generates more equitable distributive and societal outcomes. ${ }^{36}$ Thereby, the ILO counters the deregulatory narrative favouring deinstitutionalization, self-regulation, and private methods of governance, which often undercut labour regulation. ${ }^{37}$

\footnotetext{
34 Tonia Novitz, Past and Future Work at the International Labour Organization: Labour as a Fictitious Commodity, Countermovement and Sustainability, 17 International Organizations Law Review 139 (2020).

${ }^{35}$ See Work for a Brighter Future, supra n. 32 at 30.

${ }^{36}$ Simon Deakin, The Contribution of Labour Law to Economic Development and Growth, University of Cambridge Working Paper No. 478 (Centre for Business Research 2016), referred to in Countouris, supra n. 25 at 11.

${ }^{37}$ Such an approach is adopted by the World Bank Group. See, e.g., the flagship reports: World Development Report 2019: The Changing Nature of Work (World Bank 2019)
} 
The Declaration reaffirms the relevance of the employment relationship, which is considered a tool providing certainty and legal protection. Still, the commitment to guarantee protection to all workers implies extending protection beyond the standard employment relationship, which is probably becoming an under-inclusive legal category. ${ }^{38}$ All workers should enjoy adequate protection in line with the Decent Work Agenda, taking into account (1) respect for their fundamental rights; (2) an adequate minimum wage, statutory or negotiated; (3) maximum limits on working time; and (4) safety and health at work (para. III B).

In formulating the above points, the Declaration largely followed the path set out by the Global Commission, although it failed to include several forward-looking proposals recommended in the report, such as the Universal Labour Guarantee. ${ }^{39}$ Crucially, the right to occupational health and safety $(\mathrm{OSH})$ at the workplace has not been elevated to the rank of fundamental principles and rights at work. Reflecting compromise logic, the guarantee of an adequate minimum wage has been enshrined, instead of the living wage suggested by the Commission. Moreover, the Declaration does not broach the idea of expanding time sovereignty ${ }^{40}$, but instead restates the need to enforce maximum limits on working time.

The third component of the human-centred agenda is 'promoting sustained, inclusive and sustainable economic growth, full and productive employment and decent work for all' (para. III C). These three underlying objectives should be achieved through adequate macroeconomic policies and development of trade, industrial, and sectoral policies promoting decent work. The Declaration points out the need to incentivize sustainable enterprises and business practices that are aligned with the human-centred approach. In addition, it stresses protecting privacy and personal data and responding to the digital transformation of work, including platform work (para. III C v). Thus, this document restates the complementary, rather than

\footnotetext{
https://www.worldbank.org/en/publication/wdr2019, with a critical note by the ILO at https://bit.ly/33qe8JJ, and Trading for Development in the Age of Global Value Chains (World Bank 2020). For a comparative analysis of this approach, contrasted with the one of the ILO, see Damian Grimshaw, International Organisations and the Future of Work: How New Technologies and Inequality Shaped the Narratives in 2019, 8 Journal of Industrial Relations 14 (2020). See also Novitz, supra n. 34 at 36-38.

${ }^{38}$ Guy Davidov, Setting Labour Law's Coverage: Between Universalism and Selectivity, 34 Oxford Journal of Legal Studies 543-66 (2014).

${ }^{39}$ The Commission has proposed a Universal Labour Guarantee that would include (a) fundamental workers' rights: freedom of association and the effective recognition of the right to collective bargaining and freedom from forced labour, child labour, and discrimination; and (b) a set of basic working conditions: an 'adequate living wage', limits on hours of work, and safe and healthy workplaces.

${ }^{40}$ This concept was used by the Commission to describe the need to assure that workers are able to exercise control over their working hours. It recommended not only effective application of maximum limits on working time, but also the implementation of a guaranteed and predictable minimum number of hours. Work for a Brighter Future, supra n. 32 at 40.
} 
mutually exclusive, character of economic and social objectives, and seeks to mitigate the underlying tension between safeguarding workers' rights and pursuing innovative business models. It calls for policy coherence between private and public actors, presupposing not only lack of contradictions, but also synergy stemming from policies pursuing a common objective. ${ }^{41}$ Digitalization should be neither an incentive nor a pretext for the arbitrary misapplication of existing labour laws and social security provisions.

\subsection{THE EU LEVEL: BUILDING A NEW SOCIAL DIMENSION}

EU social policies addressing non-standard forms of work represent an increasingly dynamic field. This section provides a brief chronological overview of the main instruments and policies that either address specific aspects of the digital transformation or aim more broadly at enhancing social policy.

Communication $\operatorname{COM(2016)~} 356$ and the Parliamentary Resolution on a European Agenda for the 'collaborative economy', released in early June 2016, emphasized that digital labour platforms are already subject to existing EU rules in areas such as competition, consumer protection, data protection, and single market freedoms. ${ }^{42}$ In a strongly pragmatic approach, the communication concludes the labour-related section by advocating an intervention by Member States aimed at 'assess[ing] the adequacy of their national employment rules' in relation 'to the different needs of workers and self-employed individuals in the digital world'.

Several other instruments addressing issues related to digitalization have limited social implications. In May 2016, the General Data Protection Regulation (GDPR) entered into force. It represents a step toward homogenizing privacy rights across nations. However, there are only a few strictly labour-related provisions. ${ }^{43}$ In June 2019, the Platform to Business or P2B Regulation on promoting fairness and transparency for business users of online intermediation services was adopted. ${ }^{44}$ Although it is not a purely social law instrument, it is aimed at opening a competitive, fair, and transparent online ecosystem and thus has relevance to some platforms mediating labour, such as freelancing platforms. ${ }^{45}$

\footnotetext{
${ }^{41}$ Velibor Jakovleski, Where Is the ILO Going with the Centenary Declaration? https://bit.ly/2BZjQs4

${ }^{42}$ Communication of 2 June 2016, A European Agenda for the Collaborative Economy (SWD(2016) 184 final).

${ }_{43}$ Antonio Aloisi \& Elena Gramano, Artificial Intelligence Is Watching You at Work. Digital Surveillance, Employee Monitoring and Regulatory Issues in the EU Context, 41 Comparative Labor Law \& Policy Journal 1 (2020).

${ }^{44}$ Regulation (EU) 2019/1150 of the European Parliament and of the Council of 20 June 2019 on promoting fairness and transparency for business users of online intermediation services.

${ }^{45}$ CEPS, EFTHEIA, and HIVA-KU Leuven, Study to Gather Evidence on the Working Conditions of Platform Workers VT/2018/032 Final Report 13 December 2019, 171-77.
} 
A new council recommendation on access to social protection for workers and the selfemployed was adopted in November 2019, ${ }^{46}$ acknowledging that the current social security coverage under-includes atypical workers. It advises Member States to ensure formal and effective coverage, adequacy and transparency of the system for 'workers and the selfemployed, including people transitioning from one status to the other or having both statuses, as well as people whose work is interrupted due to ... the risks covered by social protection'. It also calls on Member States to review the rules governing contributions and entitlements so that they do not constitute undue obstacles to benefits for people who perform work of exceedingly low duration in a discontinuous way, with limited earnings. ${ }^{47}$ The margin of discretion left to states to decide on how to re-organize social protection systems may limit the impact of this tool in tackling economic uncertainty.

In her mission letter to Commissioner-designate Nicolas Schmit, President von der Leyen called for strengthening Europe's social dimension through - among other means 'dignified, transparent and predictable working conditions [which] are essential to our economic model'. There was also a specific mandate to 'monitor and enforce existing EU law in this area and to look at ways to improve the labour conditions of platform workers' ${ }^{48}$ In January 2020, a new 'Agenda for a strong social Europe' was announced, including proposals to empower people through quality education, training and skills; foster equality; promote fair working conditions (with a reference to a 'Summit' dedicated to discussing priority issues and possible solutions for platform workers); secure high social protection; and fight poverty and exclusion. ${ }^{49}$ In October 2020, the Commission adopted its 2021 Work Programme, which includes a legislative proposal to improve the working conditions of platform workers and ensure adequate social protection.

\subsubsection{The European Pillar of Social Rights}

In January 2017, the European Parliament adopted a resolution on the European Pillar of Social Rights in which it advocates 'for work intermediated by digital platforms ... a clear distinction - for the purpose of EU law and without prejudice to national law — between those genuinely self-employed and those in an employment relationship, taking into account ILO

\footnotetext{
${ }^{46}$ Recommendation of 8 November 2019 on access to social protection for workers and the self-employed (2019/C 387/01).

${ }^{47}$ Paul Schoukens, Alberto Barrio, \& Saskia Montebovi, The EU Social Pillar: An Answer to the Challenge of the Social Protection of Platform Workers? 20 European Journal of Social Security 219-41 (2018).

${ }^{48}$ Ursula von der Leyen, Mission letter to Nicolas Schmit, Commissioner-designate for Jobs. Brussels, 10 September 2019.

${ }^{49}$ Communication of 14 January 2020, A Strong Social Europe for Just Transitions (COM(2020) 14 final).
} 
Recommendation No 198, according to which the fulfilment of several indicators is sufficient to determine an employment relationship'. ${ }^{50}$ The resolution stresses that 'those employed as well as those genuinely self-employed who are engaged through online platforms should have analogous rights as in the rest of the economy' (emphasis added).

Later that year, the European Commission presented its proposal on the EPSR in two legal forms with identical content: a commission recommendation, ${ }^{51}$ adopted on the basis of Article 292 TFEU and consequently lacking any robust enforceability mechanism vis-à-vis Member States, and a proposal for an interinstitutional proclamation by the parliament, the council, and the commission. ${ }^{52}$ The EPSR was proclaimed at the Social Summit for Fair Jobs and Growth in Gothenburg, Sweden, in November 2017. This instrument is aimed at achieving 'upward convergence' towards better working and living conditions across the EU through a blend of pending initiatives and new legislation. ${ }^{53}$ The new Commission is expected to turn commitment into decisive action, and President von der Leyen formally asked the commissioner for jobs and social rights to 'develop an action plan to implement the Pillar'. ${ }^{54}$

There has been much discussion about the legal nature of this 'uncommon' measure, which is difficult to situate in the traditional taxonomy of EU instruments. The most that can be agreed is that it is a high-profile political re-affirmation of a broad set of social rights and principles. Its value is mainly symbolic: according to its preamble, indeed, it is nothing more than a guide (a 'compass'). As a consequence, 'to be legally enforceable, the principles and rights first require dedicated measures or legislation to be adopted at the appropriate level' ${ }^{55}$ In a narrow sense, the EPSR consists of 20 'rights and principles' classified into three broad groups of recommendations: (1) equal opportunities and access to the labour market, (2) fair working conditions, and (3) social protection and inclusion. The second section is more pragmatic and presents four concrete propositions encompassing contracts, wages, information about employment conditions and protection in case of dismissals, and social dialogue and involvement of workers.

The document also advocates preventing 'employment relationships that lead to precarious working conditions'. According to S. Garben, the initiative aims 'to provide new

\footnotetext{
${ }^{50}$ European Parliament resolution of 19 January 2017 on a European Pillar of Social Rights (2016/2095(INI))

${ }^{51}$ Commission Recommendation of 26 April 2017 on the European Pillar of Social Rights, C(2017)2600final.

${ }^{52}$ Interinstitutional Proclamation on the European Pillar of Social Rights (2017/C 428/09). To this must be added Communication of 26 April 2017, Establishing a European Pillar of Social Rights, COM/2017/0250final.

${ }^{53}$ Sacha Garben, The European Pillar of Social Rights as a Revival of Social Europe (2019), https://bit.ly/3dyQa2I

${ }^{54}$ von der Leyen, supra n. 48.

${ }^{55}$ Frank Hendrickx, The European Pillar of Social Rights: Interesting Times Ahead, 191-92 (2017).
} 
and tangible minimum protection and security for workers in atypical employment and for the (dependent) self-employed' ${ }^{56}$ From a social convergence perspective, the EPSR package could expand the personal scope and increase the level of protection afforded for certain groups of people (e.g., non-standard workers, self-employed workers, or unemployed people) who still fall through the cracks of legal classification or find themselves on the margins of the job market in the digital era. Although this package should also elucidate how the political institutions understand social rights and principles, preliminary results have failed to live up to its expectations.

\subsubsection{The Directive on Transparency and Predictability}

A first legally binding follow-up to the EPSR is the new Directive (EU) 2019/1152 on transparent and predictable working conditions. This act marks the start of a much-needed adaptation of pre-existing directives in the social field to the new needs emerging from the 'digital transition'. The revision of the previous Directive 91/533/EEC afforded an opportunity for the EU to respond to a 'new generation' of non-standard forms of work. Although the significance of this legal tool is per se limited, it has gained importance, if not popularity, for two main reasons. First, the directive was the first stone laid down for building the Pillar. Second, it offers insight into the quality of implementation of EU legislation and new policy options adopted.

The 'nuanced hybrid' personal scope of this new instrument is a matter of controversy because of its ambiguity. ${ }^{57}$ Pursuant to Art. 1 (2), the minimum rights it lays down apply to 'every worker in the Union who has an employment contract or employment relationship as defined by the law, collective agreements or practice in force in each Member State with consideration to the case-law of the Court of Justice'. The 'restrained' formula blends Member States' sovereign margin of appreciation in defining an employment relationship with a consideration of the case-law of the CJEU. ${ }^{58}$ As long as they fulfil the indicators defined by the CJEU, domestic, on-demand, intermittent, voucher based, and platform workers, trainees, and

\footnotetext{
${ }^{56}$ Sacha Garben, Protecting Workers in the Online Platform Economy: An Overview of Regulatory and Policy Developments in the EU (Publications Office of the European Union 2017).

${ }^{57}$ Bartłomiej Bednarowicz, Delivering on the European Pillar of Social Rights: The New Directive on Transparent and Predictable Working Conditions in the European Union, 48 Industrial Law Journal 604-23 (2019).

${ }^{58}$ Antonio Aloisi, Platform Work in the European Union: Lessons Learned, Legal Developments and Challenges Ahead (European Union 2020). https://ssrn.com/abstract=3556922. The same formula is used in Directive EU 2019/1158 of the European Parliament and of the Council of 20 June 2019 on work-life balance for parents and carers and in the Proposal for a Directive on adequate minimum wages in the EU (COM(2020) 682), adopted based on Article 153 TFEU on working conditions.
} 
apprentices fall within the scope of this directive and are entitled to a set of minimum rights, regardless of the number of hours they actually work. Nevertheless, under a narrow interpretation of domestic law, people in the categories mentioned in the directive would not fall under its scope, as they are engaged as self-employed workers. However, the jurisprudence of the CJEU is inclined to disregard national definitions to give effect to EU regulatory tools. This practice has resulted in the development of an almost independent meaning of the term 'worker' in some fields. ${ }^{59}$ A purposive interpretation of the directive's protective aims could lean towards including non-standard workers. ${ }^{60}$ Who then could benefit from enhanced predictability and transparency, if not non-standard workers? The legal classification of workers represents, yet again, both a battlefield and an opportunity for dialogue and cooperation between courts. Undeniably, the inability to craft a broad and uniform, though sector-specific, concept of 'worker' represents a missed opportunity, even more so when one considers the broad scope of application presented in the original proposal, derived from the CJEU case law on the free movement of workers enshrined in Article 45 TFEU. ${ }^{61}$

As Principle 7 of the EPSR states, 'workers have the right to be informed in writing at the start of employment about their rights and obligations ...'. The directive further specifies the information that must be disclosed and how this is to be achieved (Art. 4 and Art. 5). In the case of work patterns that are 'entirely or mostly unpredictable', it provides that workers must be informed about the variable organization of their work and the number of guaranteed paid hours. They have a right to information on how they will be paid for the additional hours worked, when exactly their tasks will commence, and within what timeframe an assignment can be cancelled (Art. $4(2)(\mathrm{m})$ ). These provisions purport to 're-standardize' on-demand and casual work, by designing a stable availability timeframe outside of which workers cannot be sanctioned for refusing to show up and inside which they must be compensated if previously agreed slots are revoked.

Especially significant is the list of minimum requirements relating to working conditions. Some of them are tailored to combat abuses in the most volatile and unsecure segments of the platform economy. Parallel engagements are allowed, while superfluous exclusivity clauses are forbidden (Art. 9). The directive envisages a set of rules aimed at

\footnotetext{
${ }^{59}$ Nicola Kountouris, The Concept of 'Worker' in European Labour Law: Fragmentation, Autonomy and Scope, 47 Industrial Law Journal 192-225 (2018).

${ }^{60}$ Martin Risak \& Thomas Dullinger, The Concept of 'Worker' in EU Law: Status Quo and Potential for Change, ETUI Research Paper-Report 140 (2018).

${ }^{61}$ Ane Aranguiz and Bartłomiej Bednarowicz, Adapt or Perish: Recent Developments on Social Protection in the EU under a Gig Deal of Pressure, 9 European Labour Law Journal 329-45 (2018).
} 
preventing and fighting abuses that may affect the use of on-demand contracts - in line with similar provisions included in the framework agreement on fixed work decades ago - or establish a 'rebuttable presumption of the existence of an employment contract or employment relationship with a guaranteed amount of paid hours based on hours worked in a preceding reference period' (Article 11). As one of the authors has argued elsewhere, ${ }^{62}$ this is a powerful legal instrument built on a solid social legal basis, enshrined in Article 153(1)(b) TFEU that, if duly enforced by the Member States and proactively interpreted by the CJEU, may deter employers from resorting to casual work, including platform work, in an unrestrained way.

\section{CONFRONTING THE AGENDAS: TOWARDS A REVITALIZED SOCIAL CONTRACT?}

The ILO's and EU's parallel responses to 'new forms of work' cannot be seen as watertight compartments. By analysing the preparatory documents and final outcomes of the 'future of work' agendas, it is possible to trace the direction of the regulatory intervention, and, more importantly, to understand whether a consensus exists on how to revitalize the social contract for the digital era. The following paragraphs attempt to assess whether the results of the recent initiatives met the initial targets.

\subsection{A BARELY NOVEL PHENOMENON AND A BARELY NEW APPROACH}

Arguably, the personal scope of relevant legal tools has dominated the debate about regulating platform work, overexposing especially the issue of the legal status of platform workers. Yet there is increasingly little, if any, disagreement among policy makers that these forms of work bear many resemblances with other and more 'traditional' non-standard forms of employment, which have been progressively regulated with specific instruments outlined in section $2 .{ }^{63}$ However, this lack of radical novelty should not imply that the supranational political players may rest on the laurels of the social acquis and previous policy narratives. A large number of workers face the looming consequences of the inefficacy of labour protection resulting jointly from deliberate attempts to circumvent employment legislation to cut costs, the lack of harmonized definitions and the ambiguity of certain areas of law. ${ }^{64}$ The emergence of the platform economy has vividly revealed the weaknesses of the current legal framework. This

\footnotetext{
${ }^{62}$ Aloisi, supra n. 58.

${ }^{63}$ CEPS, EFTHEIA, and HIVA-KU Leuven, supra n. 45.

${ }^{64}$ Judy Fudge, Fragmenting work and fragmenting organizations: The contract of employment and the scope of labour regulation, 44 Osgoode Hall LJ, 609-48 (2006).
} 
phenomenon should be taken as a much-needed wake-up call to reassess it and to make adjustments, where needed.

Regrettably, our overview of the Centenary Declaration leads us to conclude that, despite its own assertion that it is 'imperative to act with urgency', this document adds little originality to the previous trends. The human-centred agenda presented by the Global Commission as a forward-looking strategy marking a shift in policy ${ }^{65}$ can be better described as a further development of the human-centred approach that dates back to the inception of the Organisation and is deeply entrenched in the ILO Constitution (1919) ${ }^{66}$ and the Declaration of Philadelphia (1944). ${ }^{67}$

The preamble of the Centenary Declaration says that it 'lies within the reach of the governments, employers and workers of the world to reinvigorate the Organization and shape a future of work that realizes its founding vision'. However, it is precisely the tripartite structure of the Organisation and its universal membership that weaken its institutional capacity, making the advancement of social measures such a difficult process. ${ }^{68}$ The ambitious proposals of policy makers are confronted with the complexity of establishing a consensus among all constituents from 187 Member States. The dire negotiations preceding the adoption of the Declaration at the $108^{\text {th }}$ ILC demonstrated how diversity of interests is likely to 'restrict the tripartite consensus to the 'lowest common denominator' in the form of a patchwork of projects designed to meet divergent 'clients' interests and demands'. ${ }^{69}$ Perhaps the most telling example is the fact that OSH has not been included in the framework of fundamental principles and rights at work, as proposed in the draft version of the Declaration, ${ }^{70}$ largely owing to the resistance of the employer group. Instead, its fundamental value for decent work has been expressly recognized (para. II D), and the resolution on this Declaration has requested the Governing Body to 'consider, as soon as possible, proposals for including safe and healthy working conditions in the ILO's framework of fundamental principles and rights at work' ${ }^{71}$

\footnotetext{
${ }^{65}$ Work for a Brighter Future, supra n. 32 at 24. The Commission saw the reorientation of the entire economy towards a human-centred growth and development path (p. 24) as a means of strengthening the social contract (p. 11).

${ }^{66}$ The mission of preventing the failure of any nation to adopt humane conditions of labour is enshrined in the preamble of the ILO Constitution (1919).

${ }^{67}$ Para II (a) of Declaration of Philadelphia affirms right of all human beings 'to pursue both their material wellbeing and their spiritual development in conditions of freedom and dignity, of economic security and equal opportunity'.

${ }^{68}$ Francis Maupain, The ILO at a Regulatory Crossroad, 53 International Organizations Law Review (2020).

${ }^{69}$ Maupain, supra n. 69 at 307.

${ }^{70} \mathrm{https}: / / \mathrm{bit} .1 \mathrm{y} / 2 \mathrm{YNlvJW}$, para. II C of the Draft Declaration.

${ }^{71}$ Resolution on the ILO Centenary Declaration for the Future of Work, para. 1.
} 
The same is true of the first legal instruments in the EPSR context, which run the risk of being trapped in the classical tensions among central institutions, supranational parties, national governments and local pressures. Hailed as a landmark opportunity for the EU to trigger a shift in policy discourse ${ }^{72}$ the recently implemented and upcoming initiatives of the EPSR might create important political momentum in times of disenchantment and distrust. They could also tackle the rising anti-EU sentiment and populist waves. However, the Pillar itself, reading very much like the outline of a bill of rights, ${ }^{73}$ does not represent a significant development in the 'constitutional imbalance', as it is based on a logic that links better performing economies with more equitable, adaptable and inclusive societies, in line with the perhaps outdated EU model of 'flexicurity'. ${ }^{74}$ The fact that it was designed for the Euro area should facilitate its acceptance and speed up its development. On closer inspection, the presumed overlap between economic cooperation and social solidarity sends a clear, but scarcely innovative message on the interdependence of these two policy areas.

All in all, the EU institutions are paralyzed in the archaic divergence between economic, currently wearing the new clothes of digital, and social objectives. ${ }^{75}$ If anything, the rapid development of tech companies makes it clear that this is a false incompatibility, since most of their comparative advantage of platforms is gained through sustained efforts to undermine existing regulation, mostly employment and social security rules, often resulting in unfair competition and in an unlevel playing field. ${ }^{76} \mathrm{~A}$ situation where power and control are concentrated may also lead to oligopolistic behaviours at the expense of workers, clients and consumers' welfare. ${ }^{77}$ Admittedly, the European Commission noted that 'regulatory grey zones are exploited to circumvent rules designed to preserve the public interest'. ${ }^{78}$ Therefore, assuming the market-oriented approach of the EU policy actors, should they give free rein to platform operators, serious unintended consequences could materialize, including the

\footnotetext{
${ }^{72}$ European Commission, Statement of President Juncker on the Proclamation of the European Pillar of Social Rights (2017), https://ec.europa.eu/commission/presscorner/detail/en/STATEMENT_17_4706.

${ }^{73}$ Florin Bonciu, The European Pillar of Social Rights: Too Little, Too Late? 18 Romanian Journal of European Affairs 60 (June 2018).

${ }^{74}$ Communication of 27 June 2007, Towards Common Principles of Flexicurity: More and Better Jobs Through Flexibility and Security $\{$ SEC(2007) 861\} \{SEC(2007) 862 $\}$

${ }^{75}$ Ane Aranguiz, Social mainstreaming through the European pillar of social rights: Shielding 'the social' from 'the economic' in EU policymaking, 20 European Journal of Social Security, 341-63 (2018).

${ }^{76}$ Harald Hauben, Karolien Lenaerts, \& Susanne Kraatz, Platform economy and precarious work: Mitigating risks, (2020) Directorate-General for Internal Policies.

${ }^{77}$ Sanjukta M. Paul, Uber as for-profit hiring hall: a price-fixing paradox and its implications, 38 Berkeley Journal of Employment and Labor Law, 233-64 (2017).

${ }^{78}$ See Introduction, $\operatorname{COM}(2016) 356$, p. 2.
} 
obstruction of start-ups and smaller scale initiatives. ${ }^{79}$ After the harsh decade of austerity, the digital economy is precisely the terrain where the goal of unleashing the potential of new, highly efficient markets could go hand in hand with the need to ensure a uniform application of social protection measures. An effective enforcement of social rules is indeed a crucial tool to boost competition and preserve the proper functioning of the internal market.

\subsection{THE LEGAL FORCE OF THE NEW INSTRUMENTS AND THE SPECIFICITY OF GOVERNANCE} METHODS

Both the ILO and the EU have decided to adopt mostly extraordinary measures to address the digital transformation of work. The legal force and enforceability of these measures vary widely: in general, the ILO's measures are characterized by low levels of obligation and precision and a (moderately) high level of delegation, while the EU's system is highly legalized, with high degrees of obligation, precision, and delegation. ${ }^{80}$ While the ILO finds itself in a 'softlaw trap' of non-binding recommendations and voluntarily ratified conventions, ${ }^{81}$ the soft-law measures at the EU level intersect with directives that are binding as to the result to be achieved by each Member State. The choice of form and methods of implementation is left to the national governments, which may result complex in those jurisdictions where the interference of EU in the social domain is not welcomed enthusiastically. If it is true that soft policy methods of coordination facilitated the development of modern policies in the past, 'beyond the limited concept of hard European legal competence in the area of social policy, ${ }^{82}$ this approach proves to be limited in current times, especially when it comes to resolving the tensions between the economic and social objectives within the current European governance. ${ }^{83}$ The EPSR will require further initiatives, including in the context of the European Semester, to raise panEuropean social standards, as both the recommendation and the proclamation are soft law instruments without legally binding force.

\footnotetext{
${ }^{79}$ Luigi Zingales, 'The digital robber barons kill innovation': the Stigler Center's report enters the senate (2019), $\underline{\text { http://bit.ly/2P4c9U6. }}$.

${ }^{80}$ Kenneth W. Abbott, Robert O. Keohane, Andrew Moravscik, Anne-Marie Slaughter, \& Duncan Snidal, The Concept of Legalization, 54 International Organization (2000), cited in Miriam Hartlapp, On Enforcement, Management and Persuasion: Different Logics of Implementation Policy in the EU and the ILO, 45 JCMS: Journal of Common Market Studies 653-74 (2007).

${ }^{81}$ Alain Supiot, The Tasks Ahead of the ILO at Its Centenary, 159 International Labour Review 126 (2020).

${ }^{82}$ Frank Hendrickx \& Pieter Pecinkovsky, EU Economic Governance and Labour Rights: Diversity and Coherence in the EU, the Council of Europe and ILO Instruments, in Global Governance of Labour Rights: Assessing the Effectiveness of Transnational Public and Private Policy Initiatives, 137 (Marx, Wouters, Rayp, \& Beke eds. Edward Elgar 2015).

${ }^{83}$ Sacha Garben, The Constitutional (Im)balance between 'the Market' and 'the Social' in the European Union, 13 European Constitutional Law Review, 23-61 (2017).
} 
The development of the EPSR is strongly reliant on political will and courage. The recent instruments are far from conducing to a homogenous international and EU-wide standard. However, despite the Pillar's intrinsic weakness, it has been argued that 'there is a good chance that sooner or later its principles will be invoked before the national and EU courts', enhancing its actual relevance and scope. ${ }^{84}$ It has been also said that the static imagery evoked by the notion of a 'pillar' does not capture the true nature and potential of the initiative, which is dynamic and fluid, wide-ranging and permeating. ${ }^{85}$ While it is foreseeable that, despite its more exhortatory than mandatory nature, the Pillar could mark a new stage in strengthening the EU's social dimension, this can happen only if solemn declarations are accompanied by political strength embedded in hard-law measures that are duly implemented at the national level, in the legislative, judicial and industrial arenas.

Similarly, the effectiveness of the ILO agenda ultimately relies on Member States' voluntary incorporation of labour standards into their legislation. While the Declaration serves as a broad policy roadmap, the responsibility to develop measures responding to the challenges of the digital revolution rests predominantly on domestic regulators. The Declaration calls on national governments to respond to challenges and opportunities relating to the digital transformation of work, including platform work (para. III C (v)), but lacks concrete guidance on how to do so in a reasonable timeframe. Notably, the progressive proposal discussed during the Future of Work Initiative and elaborated by the Global Commission to develop an international governance system for labour platforms has not been adopted by the ILO constituents. $^{86}$

More openness towards decentralized, layered models of governance would be desirable at both supranational levels. Already in early days of the platform economy, the EU Commission has considered 'principles-based self-regulatory/co-regulatory measures, including industry tools for ensuring application of legal requirements and appropriate monitoring mechanisms' as a viable governance option. ${ }^{87}$ Regrettably, this proclamation has not been thus far translated into a polycentric model of co-regulation engaging multiple

\footnotetext{
84 Zane Rasnača, (Any) Relevance of the European Pillar of Social Rights for EU Law? (2017), http://bit.ly/37vCUYS

${ }^{85}$ Sacha Garben, The European Pillar of Social Rights: An Assessment of its Meaning and Significance', 14 European Constitutional Law Review 210-30 (2018)

${ }^{86}$ The Report of the Global Commission has noted that it would be desirable to envisage such a system that would set minimum rights and protections, and require platforms and their clients to respect certain minimum rights and protections. As a model of such governance, the commission has pointed towards the Maritime Labour Convention, 2006, which has established a global standard for seafarers.

${ }^{87}$ Communication of 2 June 2016, A European Agenda for the Collaborative Economy, at 5.
} 
stakeholders, including technological companies, social partners and non-governmental organisations. ${ }^{88}$ Such a hybrid yet coordinated governance method could surpass the limitations of top-down regulation. It could help to bridge the governance gap resulting from two intrinsic features of the digital transformation: (i) velocity of the technological advancements outpacing the standard regulatory procedures, and (ii) the information asymmetry between tech companies disposing of data driving their operations and the regulators, whose understanding of the underlying digital infrastructure is still imperfect. ${ }^{89} \mathrm{We}$ argue that new forms of institutional layering and multilevel architecture would not run counter to the institutions' objectives. The best course of action would be to envisage a 'smart mix' of public and private governance mechanisms.

\subsection{THE RELEVANCE OF A COLLECTIVE GOVERNANCE AND SOCIAL DIALOGUE}

As argued in the previous section, the rapidly changing nature of those forms of work enabled by digital transformation could be better addressed by elastic policy instruments, including those belonging to the traditional arsenal of collective autonomy. Yet, the documents analysed here give scant consideration to traditional and modern involvement tools.

The Declaration merely reiterates the status quo with regard to collective bargaining, saying that it constitutes one of essential elements of ILO action (para. II B), and that the Organisation needs to direct its efforts to secure freedom of association. It considers the effective recognition of the right to collective bargaining as an enabling right (para. II(A)(vi)) and reiterates that effective workplace cooperation should respect collective bargaining (para. II C). The document does not address the revitalization of collective representation called for by the Global Commission. The EU's discourse is more dynamic, with the Commission intending to 'explore ways to promote social dialogue and collective bargaining and increase the capacity of unions and employer organisations at EU and national level' and to 'make full use of existing instruments on workers involvement such as the European Works Councils to promote the culture of information and consultation of workers' ${ }^{90}$ In one of her first public

\footnotetext{
${ }^{88}$ Such a model has been advocated by inter alia Michèle Finck, Digital co-regulation: designing a supranational legal framework for the platform economy, European Law Review, 47-68 (2019).

${ }^{89}$ Sangeet Paul Choudary, The architecture of digital labour platforms: Policy recommendations on platform design for worker well-being, International Labour Office - Geneva: ILO (2018)

${ }^{90}$ Communication of 14 January 2020, A Strong Social Europe for Just Transitions (COM(2020) 14 final). Similarly, in 2019, the High-Level Expert Group on the Impact of the Digital Transformation on EU Labour Markets recommended 'reinvigorat[ing] social dialogue through intensified and better organised dialogue of workers and social partners especially in the platform economy' and has invited 'both unions and employers as well as platform operators to participate in an ongoing exchange for improved collective outcomes (Social
} 
appearances, Vice President Margrethe Vestager claimed that it is crucial to 'make sure that there is nothing in the competition rules to stop those platform workers from forming a union, to negotiate proper wages as ... in any other business'.${ }^{91}$ More recently, the EU Commission launched 'a process to ensure that the EU competition rules do not stand in the way of collective bargaining for those who need it'. ${ }^{92}$

These issues are on the policy radar, at least in terms of declarations of intent. However, the risk is that a static interpretation of EU competition law could further exacerbate the Kafkian situation of platform workers and many other vulnerable own-account workers who are unreasonably treated as 'undertakings' for the purposes of EU antitrust law without having the possibility of controlling their work processes, the prices of their 'services' and, more broadly, their conduct in the market. ${ }^{93}$ It is essential to ensure that those workers disenfranchised because of their employment status can effectively exercise the fundamental right to collective bargaining, recognized by international law instruments to 'workers' in general, without making a distinction between standard and non-standard categories. This can be achieved through an update of the current legal framework and, where appropriate, the adoption of a new interpretation of the antitrust categories, in order to allow larger segments of the labour force to improve working conditions and, thereby, to help promote inclusive and sustainable growth.

Parallel to this legal barrier, the digital transformation triggers a need to seek new forms of collective voice. A legal environment friendly to such collective forms should be secured, overcoming the limitations of the classical, albeit to some extent eroding model centred on standard employment relationship (SER).${ }^{94}$ Social dialogue and collective bargaining represent flexible solutions to promote fair conditions for non-standard workers, while legislation and legal claims have been struggling to respond promptly and adequately to the current scenario. Moreover, inventive involvement mechanisms will become increasingly important with

\footnotetext{
Dialogue)'. European Commission, Report of the HLEG on the Impact of the Digital Transformation on EU Labour Markets (Luxembourg 2019).

${ }_{91}$ Javier Espinoza, Vestager Says Gig Economy Workers Should 'Team Up' on Wages, Financial Times, 24 October 2019, https://on.ft.com/2pPHst2.

${ }^{92}$ See https://ec.europa.eu/commission/presscorner/detail/en/IP_20_1237.

${ }^{93}$ C-413/13, FNV Kunsten Informatie en Media contro Staat der Nederlanden [2014] ECLI:EU:C:2014:2411, para 36. Eva Grosheide \& Beryl ter Haar, Employee-Like Worker: Competitive Entrepreneur or Submissive Employee? Reflections on ECJ, C-413/13, FNV Kunsten Informatie, 21 (Łaga, Bellomo, Gundt, \& Miranda Boto eds. Gdańsk University Press, 2018).

${ }^{94}$ Background paper for discussion at the ILO-AICESIS-CES Romania International Conference (Bucharest, 1011 October 2019), https://www.ilo.org/global/docs/WCMS 723431/lang--en/index.htm; Antonio Aloisi, Negotiating the Digital Transformation of Work: Non-standard Workers' Voice, Collective Rights and Mobilisation Practices in the Platform Economy (EUI Working Paper 2019).
} 
intensified algorithmic managerial control at the workplace, the growth of new forms of employment and the risk of technological displacement. ${ }^{95}$

There is more: non-standard workers are developing new engagement techniques, shaping collective agency and promoting effective renegotiation of their work arrangements. ${ }^{96}$ These initiatives can be either assisted, if not even led, by long-established unions or promoted by grassroots movements. The most convincing strategy for ensuring decent work in the platform economy should be an embedding of platform workers, across the entire spectrum of practices, 'from organising workers and engaging in information and consultation exchanges with platforms through to collective bargaining and co-determination' ${ }^{97}$ From a pragmatic point of view, effective trade union strategies would be based on the negotiation of encompassing collective agreements, extending negotiated outcomes to non-standard workers. ${ }^{98}$ At the same time, there is a need to increase the importance of organising the transborder platform work, considering that in many cases there is no limitation of the physical location where the services are completed and consequently several national legal systems and jurisdictions may be implicated.

\subsection{THE LONG WAY TO UNIVERSALISM}

The endeavour to move towards universal protection permeates both supranational agendas. The EU's recommendation on access to social security, which does not apply to social assistance and to minimum income protection schemes, invites Member States to tailor the rules to specific groups while maintaining a general principle of universality. Also, the GDPR applies regardless of employment status. However, given the instrument's goal, it is doubtful whether the legislative technique adopted has the right credentials to become the new standard.

The initial stages of work on the Directive 2019/1152 have generated many expectations, which eventually turned out to be hard to be fulfilled with one single legal document. It was hoped that this Directive would not only be a response to the platformization of the labour market but, more generally, would crystallize and advance the EU social acquis

\footnotetext{
95 Valerio De Stefano, Negotiating the Algorithm: Automation, Artificial Intelligence and Labour Protection, Employment Policy Department Working Paper No. 246 (2018).

${ }^{96}$ Hannah Johnston and Chris Land-Kazlauskas, On Demand and Organized: Developing Collective Agency, Representation and Bargaining in the Gig Economy, ILO Conditions of Work and Employment Series No. 94 (2018).

${ }^{97}$ Jeremias Prassl, Collective Voice in the Platform Economy: Challenges, Opportunities, Solutions, Report to the ETUC (2018) at 20.

${ }^{98}$ Minawa Ebisui, Non-standard workers: Good practices of social dialogue and collective bargaining, E-Journal of International and Comparative Labour Studies, 211-246 (2012).
} 
by broadening its personal scope in the area of fair contractual terms. What has been achieved is the acknowledgment of the fact that providing workers with thorough, correct, and timely information is a critical pre-requisite for enforcing and improving working conditions, especially for those workers who are prone to experiencing precarious situations. ${ }^{99}$ However, the stuttering results in defining the personal scope of the document may jeopardize the effective and adequate application of this protective tool for non-standard workers in Europe. ${ }^{100}$ If a very light set of requirements related to transparency and stability has encountered such strong resistance by Member States during the course of the negotiations on the Directive, it is doubtful whether more can be achieved in other areas where conflictual forces may result overwhelming.

Also as regards the ILO, to put it bluntly, applying a truly inclusive and forward-looking system of protection regardless of the worker's contractual status remains easier said than done. Regrettably, the Conference did not approve even the Draft Declaration's recognition that '[a]ll workers, regardless of their employment status or contractual arrangements, should be guaranteed: (i) respect for their fundamental rights; (ii) an adequate living wage; (iii) limits on maximum working hours; (iv) safety and health at work'. The explicit formulation 'regardless of their employment status or contractual arrangements' was opposed by inter alia the government members of the EU Member States. ${ }^{101}$ Nor have privacy and personal data protection been guaranteed as rights of all workers regardless of their status (Draft Declaration para. III B (v)). It is thus left to the Member States to protect their nationals' privacy and personal data; the ILO does not assume any commitment, though it maintains its broad mandate to provide technical assistance (para. III C (v)).

While we are aware of the difficulties intrinsic in the policy making process at both supranational levels, it cannot be emphasised strongly enough that labour regulation needs to be extended to workers who are still unreasonably excluded from the scope of employment law because of the construction and the rigid interpretation of existing categories. It is to be wished that this renewed activism will trigger the implementation of a social agenda promoting rights for workers, regardless of their (genuine or carefully crafted) contractual classification. Instead of small, gradual steps, we expect a decisive change both at the judicial and legislative level.

\footnotetext{
${ }^{99}$ Bednarowicz, supra n. 57.

${ }^{100}$ Izabela Florczak \& Marta Otto, Precarious Work and Labour Regulation in the EU: Current Reality and Perspectives, in Precarious Work, 3 (Kenner, Florczak, \& Otto eds. Edward Elgar, 2019).

${ }^{101}$ Report of the Committee of the Whole: Summary of Proceedings, ILC108-PR6B(Rev.), https://bit.ly/31w7VfX, para. 1133.
} 
Firstly, domestic judges ought to develop an elastic understanding of the concept of worker, including in the field of collective rights, in order to make labour regulation effective and to promote legal certainty. Such an interpretation would be also beneficial for new economic players in the digital economy. Indeed, more effective compliance mechanisms will surely afford concrete solutions, to the advantage of workers and competitors operating in the same industries.

Secondly, consideration should be given to legislative instruments at the European and international level which would introduce an ampler notion of 'worker' to deliver the right to adequate labour and social protection. One could conceive various avenues which could lead to fulfilling this fundamental goal, i.e. delinking protection from the narrowly defined notion of worker. Numerous laudable and original proposals are being put forward in scholarship in this regard. Without intention of favouring any particular approach, nor claiming that we provide an exhaustive list of noteworthy academic initiatives, we signal some of them. There is a sizeable body of extant literature, reinforcing the call towards strengthening social acquis and ensuring greater inclusiveness, from which policy makers could indubitably draw much inspiration.

In more concrete terms, thinking of the EU level, one viable approach would be to introduce a new directive amending the scope of the existing ones horizontally. Another idea could be to leverage the CJEU's adaptable interpretation. ${ }^{102}$ Further, academics have proposed to define personal work within the scope of labour protection, as encompassing any 'person [who is] engaged by another to provide labour and is not genuinely operating a business on his or her own account'. ${ }^{103}$ Such a broad notion of work should be forged without weakening the very notion of employment. ${ }^{104}$ If not feasible, another solution could be the implementation of a single directive ensuring equal treatment between all forms of non-standard work and standard work. ${ }^{105}$ Moreover, as regards the international legal framework, what could be envisaged is a new type of regulatory instrument going beyond declarations, conventions, and recommendations, which would require a thorough overview of all forms of work, including work beyond wage employment. ${ }^{106}$ Yet another unprecedented initiative would be a horizontal

\footnotetext{
102 Sacha Garben, Claire Kilpatrick, \& Elise Muir, Towards a European Pillar of Social Rights: Upgrading the EU Social Acquis, College of Europe Policy Briefs No. 1 (2017).

${ }^{103}$ Nicola Countouris \& Valerio De Stefano, New Trade Union Strategies for New Forms of Employment, 49 (Etuc, Brussels 2019).

${ }^{104}$ Countouris, supra n. 25 at 13.

105 Hauben, Lenaerts, \& Kraatz, supra n. 77.

${ }^{106}$ Supiot, supra n. 82 at 126.
} 
instrument - a recommendation for the ILO that would apply to its supervisory bodies, its constituents, and the office. Such a recommendation would call for a broad interpretation of existing conventions and recommendations, reaching beyond the scope of formal salaried employment unless specific instruments expressly provide for a narrower scope. ${ }^{107}$

This sketchy overview of scholarly literature makes it even more apparent that there is a vast room for the ILO and the EU to do more in order to advance their social acquis than their current agendas foresee. Although no consensus exists on the best way to proceed, there is no denying that further action is needed to decouple protection from the notion of worker. The fulfilment of subordination criteria shall not be the exclusive 'gate' determining entitlement to labour rights. This is the site of the greatest need for legal intervention.

\section{WILL 'FESTINA LENTE’ BE ENOUGH? CONCLUDING REMARKS}

The past few years have seen strenuous endeavours by the ILO and the EU to respond to the socio-legal challenges brought about by the technological revolution. While much of the current framework is relevant to new and emerging forms of digital work, there is no room for complacency that the existing laws are (and will be) entirely 'fit for the purpose' in the years to come. A global consensus is shaping up that the challenges posed by digital transformation should not be addressed solely at the national level. Within their mandates, the ILO and the EU are in the best position not only to stimulate the multi-pronged discussion on the future of work, but to adopt effective, collective and cutting-edge responses.

A reader looking for an enthusiastic overview of innovative policy measures may be left dissatisfied. As we have argued, no radical shift has been achieved at either of the levels analysed. The policy approach towards new forms of work has been akin to that of the past, focusing on bringing non-standard workers under the protective scope of labour law by stretching the notion of employment and countering sham self-employment, as well as extending some work-related rights beyond employment. To date, there have been no initiatives aimed at further normalization through dedicated regulation or hard-law instruments tailored for the new forms of work (e.g., a directive or convention on platform-mediated work). Nonetheless, the lack of regulatory measures does not necessarily imply institutional ignorance or, a reckless blessing on the many harms affecting many workers all over the world and in Europe as well. Paradoxically, the absence of specific - or, even worse, one-size-fits-all -

${ }^{107}$ Countouris, supra n. 25 at 13. 
provisions reveals a praiseworthy reluctance to authorize interventions that are too narrow and therefore prone to rapid obsolescence or selective disapplication.

The vast bulk of policy makers' energies should be concentrated not on 'reinventing' legal-conceptual forms and corollary rights and obligations, but on their more reliable inspection and enforcement. One of the major challenges in this regard is the aforementioned information asymmetry, which hinders the oversight capacity of public authorities unless relevant data is shared by the companies. ${ }^{108}$ Thus, mandating transparency of companies' internal and external operations is the first, necessary step without which monitoring and enforcement of labour and social rights (including core labour standards such as the antidiscrimination principle) is bound to fail. Moreover, far-reaching control mechanisms typically put in place by digital platforms with relation to various aspects of work performance could be harnessed in order to stimulate compliance with applicable regulations. Indeed, both social partners and platforms are well-placed to monitor working time regulations, minimum hourly wage, equal pay or application of OSH regulations. This brings us back to our previous point regarding the need for a greater involvement of collective and industry actors in designing compliance schemes and monitoring mechanisms. ${ }^{109}$ At the EU institutional level, instead, the newly created European Labour Authority (ELA) could be conferred on new tasks in this area to advance its role a 'continental' labour inspectorate.

Further tightening of institutional ties is very welcome, not least in light of the ILO's commitment to promote greater coherence within the multilateral system reaffirmed in the Centenary Declaration. ${ }^{110}$ Delivering on this mandate requires stronger cooperation not only across the UN system ${ }^{111}$ but also with regional intergovernmental organizations such the EU. Moreover, the ILO's engagement in a deeper partnership with the EU could be seen as a form of institutional layering that would help to reach the ILO's governance objectives. The

\footnotetext{
108 Choudary, supra at 90. Agnieszka Piasna, Counting gigs. How can we measure the scale of online platform work?, ETUI Research Paper-Working Paper (2020).

109 Antonio Garcia-Muñoz Alhambra' Beryl Ter Haar, \& Attila Kun, Harnessing Public Institutions for Labour Law Enforcement: Embedding a Transnational Labour Inspectorate within the ILO, 17 International Organizations Law Review 233-60 (2020).

110 The Declaration pronounces that '[o]n the basis of its constitutional mandate, the ILO must take an important role in the multilateral system, by reinforcing its cooperation and developing institutional arrangements with other organizations to promote policy coherence in pursuit of its human-centred approach to the future of work, recognizing the strong, complex and crucial links between social, trade, financial, economic and environmental policies', para. IV F.

${ }^{111}$ In September 2019, the UN General Assembly endorsed the ILO Centenary Declaration and called on UN bodies to consider integrating the Declaration's policy proposals into their work; see the note at https://www.ilo.org/moscow/news/WCMS 719183/lang--en/index.htm
} 
'internalization' of core ILO concepts by the EU in its agenda could generate a 'multiplier effect' and thus increase the significance of the Declaration. ${ }^{112}$ The conclusions adopted by the EU Council on 24 October 2019 call on the European Commission to update its 2006 communication 'Promoting Decent Work for All - The EU Contribution to the Implementation of the Decent Work Agenda in the World' in light of the Declaration, the EPSR, and the 2030 Agenda for Sustainable Development. ${ }^{113}$ Arguably, the concept of 'decent work' has been already integrated at the EU level in the EPSR. ${ }^{114}$

It remains to be seen how both institutions will continue to enhance their collaboration in the area of employment and social policies. ${ }^{115}$ It will be particularly interesting to see whether any ILO-EU joint initiative will emerge concerning the digital transformation, e.g., on platform work or AI. UN Secretary-General António Guterres, at the Paris Peace Forum in November 2019, pointed to the EU as an institution that 'must continue to shape the digital age and be at the frontline of technological regulation'. ${ }^{116}$ In particular, he drew attention to the GDPR as a measure 'setting an example and inspiring similar measures elsewhere in the world'. The ILO could indeed learn from the European innovative approach to increasing transparency and 'algorithmic accountability' or ensuring workers' sovereignty over data. ${ }^{117}$ The 'human-incommand approach' - a term often used in the EU in the specific context of the interaction between humans and artificial intelligence ${ }^{118}$ - is certainly but one vital aspect of the 'human centred approach' adopted by the Declaration.

To conclude, the broadly conceived 'future of work' agendas of the ILO and the EU are

\footnotetext{
112 Velibor Jakovleski, Scott Jerbi, \& Thomas Biersteker, The ILO's Role in Global Governance: Limits and Potential, International Development Policy | Revue internationale de politique de développement [Online], 2019, http://journals.openedition.org/poldev/3026.

113 The Future of Work: The European Union Promoting the ILO Centenary Declaration Council Conclusions (24 October 2019), https://data.consilium.europa.eu/doc/document/ST-13436-2019-INIT/en/pdf, para. 31.

${ }^{114}$ Paul van der Heijden, The ILO Stumbling towards Its Centenary Anniversary, 15 International Organizations Law Review 218 (2018).

${ }^{115}$ Francesco Pastore, Simonas Gausas, Izabela Styczyńska, et al., EU and ILO: Shaping the Future of Work, Study for the Committee on Employment and Social Affairs, Policy Department for Economic, Scientific and Quality of Life Policies (European Parliament, Luxembourg, 2019); European Union-ILO Cooperation Factsheet, May 2019, see https://bit.ly/2ZucHYC

116 See https://bit.ly/2YORCJh

117 The importance of these measures was mentioned in the Global Commission Report ('the exercise of algorithmic management, surveillance and control, through sensors, wearables and other forms of monitoring, needs to be regulated to protect the dignity of workers. Labour is not a commodity; nor is it a robot,' p. 43).

118 The European Economic and Social Committee advocates that 'workers must be involved in developing these kinds of complementary AI systems in order to ensure that the systems are useable and that the worker still has sufficient autonomy and control (human-in-command), fulfilment and job satisfaction'. See paras 2.6 and 4.25 of Artificial Intelligence - The Consequences of Artificial Intelligence on the (Digital) Single Market, Production, Consumption, Employment and Society (own-initiative opinion), https://bit.ly/2NND5ra
} 
following similar trajectories. Despite the high number of detailed analyses of regulatory fitness and impact, this moment of reflection has been accompanied by a rather slow execution. There is a stark mismatch between the aspirational calls to act with urgency and the realization of policies, along the lines of 'festina lente'. However understandable this may be for two institutions with complex governance structures and often conflicting stakeholders, it is important to prevent caution from turning into paralysis. As the Global Commission powerfully stated, 'without decisive action we will be sleep-walking into a world that widens inequalities, increases uncertainty and reinforces exclusion, with destructive political, social and economic repercussions'. ${ }^{119}$ If the preliminary agendas of the ILO and the EU seem to be pointing in the right direction, more courage is needed in their execution, so that these stepping stones do not lead to a dead end.

We are convinced that the most effective way to ensure the longevity of these two institutions and the most concrete antidote to the growing hostility towards their projects lie in their capacity to lead action to reshape the changing world of work. We hope that the crosslevel analysis we have offered in this paper will shed some light on the way towards a new social contract, and on the challenges to implementing it.

${ }^{119}$ Work for a Brighter Future, supra n. 32 at 21. 